\title{
Contemplating Arts Education: An Interview with Lee Worley by Daniel Plá
}

\section{Lee Worley* Daniel Plá**}

* Professsor Emerita, Naropa University, Arapahoe Avenue, Boulder, Colorado

** Universidade Federal de Santa Maria (UFSM), Avenida Roraima 1000, Santa Maria, CEP 97105-900, Brazil.

KEYWORDS

Contemplative Education Contemplative Practice

Naropa University

Mudra Space Awareness

\section{ABSTRACT}

An interview with Lee Worley, conducted in 2016, discussing the history of contemplative arts at Naropa University, and the relationship between contemplative practices and performer training.

\section{A BRIEF INTRODUCTION}

This interview with Lee Worley occurred during a 10-day Mudra Space Awareness retreat which she was guiding at Dechen Chöling (France) in April 2016. Worley is an actress, director and contemplative educator. She was a founding member of the Open Theater with Joseph Chaikin. She also toured Europe with The Living Theater and has taught acting at the New School for Social Research and at Sarah Lawrence College. As a student of Chögyam Trungpa Rinpoche, one of the first teachers of Tibetan Buddhism in the US, she was the founder in 1976 of Naropa University's Theater Department. She collaborates with scholars and artists all over the world, teaching performance and Mudra Space Awareness - a practice to synchronize mind, speech and body. Its origins rest in Trungpa's experience of monastic dance during his training in Tibet. Originally directed at performers, Mudra practice can also be useful for anyone who wishes to tune their mind-body connection and develop a heightened state of awareness and creativityi.

In this interview, we began by recollecting part of Naropa's history, and its vision of contemplative approaches to arts and education, as a starting point from which to discuss the relationship between contemplative practices and performer training. During our conversation we approached themes such as interdisciplinary approaches to education, the role of technique and its delicate connection to mindfulness, and Buddhist practice and training as a way of investigating suffering (Dukkha) and afflictive states of mind (Kleshas) in order to widen our liberty and awareness. May this transcript be of benefit to all beings. 


\section{DANIEL}

So, just to start the conversation, I'd like to ask you to talk a little bit about the history of Naropa. As you were one of the founders, I'd like to ask how the experience was, for you, of making this programme. I think it was the first curriculum in contemplative art in Higher Education, is that right?

\section{LEE}

No doubt. There are definitely church schools, but as a kind of Buddhist inspired school... there wasn't anything like that around at all in the States.

How was it? Well, first of all, the people who started the school were artistic and academic people to whom Trungpa Rinpoche said, 'Would you come and start a theatre programme, would you come and do the writing programme, would you come and teach philosophy, would you come and teach Tai Chi?' It was very much his invitation to certain people, who had, for one reason or another, been in his sights. And the way they came into his sights was because there had been two Naropa Summer Institute programmes, where almost anybody with anything had been invited and people came Ram Das came and scholars and Buddhists came, and artists like myself and other people came and taught, and the programme was this basket of richness of different fields of stuff. And then we - those of us who came - got kind of hooked on it. I don't know, maybe there were people who had a meditation practice before this event, but certainly, speaking for myself, I didn't have any meditation at that time.

I had had a teacher who was a student of Gurdjieff. And I had been dutifully trying to follow the expectations of that teacher although it wasn't working for me very well for a number of reasons, not all of them having to do with Gurdjieff's work, but also with my own lifestyle and my own confusion. So I was definitely someone who was seeking. And perhaps that was true of many of these people. It was a time when people were really seeking - through drugs, through craziness, through this, that, and the other thing.

Starting the programme didn't happen for quite a long time. It was just scattered classes in the beginning. Then, in '76 the idea developed that we should have a year-round course of study and Reggie Ray, who at that time was trying to be the head of faculty, was working to engage the faculty in spelling out a rough curriculum of study rather than just class, class, class. And his curriculum of study, since he was a Buddhist Studies scholar, was built around the Three Yana approach; you know, you start in Hinayana, move to Mahayana, and Vajrayana, maybe, later.

So that was very helpful to me, since I wasn't coming from any approach at all. I mean, I first went to drama school, but I had been teaching with the Open Theater for as long as I was in the Open Theaterii. I was pretty much teaching improvisational things from early on but never with any regimen, or 'This comes first and then that'; it was all just sort of intuitive. 
One of the things that really helped build the school was that there were not a lot of us, and we were from very different fields of study. All of us were committing ourselves to meditation and to an idea of how meditation and whatever discipline that we had could help each other, or come together, or work for us, or something.

We used to have wonderful discussions, just wonderful discussions, with lots of sake and a lot of late nights, and arguments, and, you know, 'What about this? What about that?' This was across the academic disciplines; it was not that the psychologists got together, or the artists got together, it was the faculty of Naropa who'd get together, and there would be these questions: How do you work with Buddhism? And how do you work with meditation?

I think that was something that was really, really important - that eye-to-eye dialogue with other people who, in a way, might have been scholars in their fields, but were babies coming into the Dharma. Every once in a while Rinpoche would come to... you couldn't really call it a faculty meeting, but it might be supper at somebody's house, and maybe Rinpoche would give a little talk about his view of education or something like that. Those talks are available ${ }^{i i i}$ in case you ever are interested in using them. They were very inspirational to us. We didn't necessarily know where he was coming from or what he was thinking, but they gave us some ideas about how to take steps in the direction of making some curriculum.

And then - what happened? It was a sort of organic evolution with a lot of twists and turns. I mean, there was a time fairly early on when it was either the Buddhist Studies or the Theatre track that had to be cancelled because there wasn't enough money to have two programmes. And I didn't think that Buddhist Studies should be cancelled, even though I was the theatre programme. But in those days it wasn't quite like it is, mostly, these days. So what happened was that I became - I don't remember what it was called - the 'coordinator' or something like that - for the Buddhist seminary ${ }^{\text {iv }}$. That meant that my way to that programme was paid and I had three months of living within it. I wasn't at school, but I was taken care of. You know, my memory of that time is very vague, but it was nice for me. It wasn't like, 'Well, we don't have room for theatre, we can't afford that, goodbye'. It was very much like, 'We're going to have to shut down some of the theatre work right now because Buddhist Studies needs the money' and, 'Would you be willing to take on this coordinating job?' The next time that they shut down the theatre programme, under Trungpa's supervision, the Buddhists had started a school to teach the more academic Dharma to Vajrayana Buddhists in the community, and I was asked if I would be willing to be the administrator of that school, so again I had a job and I could keep my teaching going. That insecurity went on for quite a while.

Then, at a certain point, somebody decided that the only way Naropa could survive was to become accredited. And there was a tremendous amount of work that went into shaping the curriculums into departments, having sort of an arc of curriculum and a beginning, middle and end and things like that. Getting accredited, having evaluations, all the 
things that go on when you start dealing with the system. But the reason it had to happen was because financial aid isn't possible for students if the school is not accredited, and we rely heavily on financial aid for many of our students. I mean, there are some people who are wealthy, but the large majority are either living on their own, making their own way in the world, or they're going to a school that's somewhat against the norm, so they may not have parents who are saying, 'Yes, we'll fund you while you go there'.

So, that was accreditation and it came along, I think, in something like ' 84 or ' 85 , I'm not sure. And it didn't change us. People say, 'Oh, yeah, that's when everything went bad', but I don't think so. I mean, it didn't really change that much, except we had more structure than before. And we got paid a little bit more often than we had before. Now, that's not a bad thing. And we acquired one of the buildings that we now own. That was a very good thing because before that we were sort of tenants in assorted spaces around town. I did a scene study class in a space that was probably no bigger than from the fireplace to the window here [We were in a space around $9 \mathrm{~m}^{2}$ ]. It was a small class, mind you; I think I only had four students and I was working on scenes from The Balcony. In this little tiny room. Oh, and not only that, but this little tiny room was within a building where, down below the second floor where this classroom was, there was a hamburger, hashbrown, potato and egg place - a restaurant - that kind of place with grease and open steam rising, and the smell of... I don't know if I'm answering your question...

\section{DANIEL}

Yes, you are. How did you apply this Buddhist approach to the theatre curriculum?

\section{LEE}

Well one of the reasons that $\mathrm{I}$ became a Buddhist was that first summer when Trungpa Rinpoche was giving talks about the Dharma about passion, aggression and ignorance as an example, a very good example - I was for the first time hearing a vocabulary, a language of words that was in line with my understanding of the way things are, based on the theatre work that I'd been doing in New York at the Open Theater, and improvisational theatre, and ensemble theatre, and so on. The things I was trying to teach my theatre students in New Mexicov - suddenly, there were words to put to them. And these things that I knew but didn't have any vocabulary for, I now could really speak about. That was a very convincing reason for me to want to study and practice Buddhism. I was finally being supported in what I had understood from improvisational performance practice.

I didn't learn it in drama school, from the Method and stuff like that. Method was never... I never could quite get it; you have to go back in your mind to get some story from your youth to bring into the present so that you can have an emotion? Why don't you just have an emotion? I mean, what's the problem? There's plenty to cry about if you want to cry! You know, I had that kind of attitude.

But the clarity of human behavior spoken of in Buddhism as passion, aggression, and 
ignorance - which obviously physicalizes as pulling towards, pushing away and ignoring can become a set of tools, or handles, for intentionality while doing improvisations. So, you know, it was just like gold to be given that. How does that fit into acting training? Well, I don't know if I even thought I was doing acting training so much as I was working with people who were young and pretty confused. Many of them were lost on a lot of levels, and really I was just trying to bring them to a place where they could function in a real, confident way. Theatre was my medium for doing that. Then, over time it became a theatre programme, so of course I had to figure out what the curriculum was. I had a really nice curriculum situation in the early days, before one of the crashes of the programme, which was that on Monday, Wednesday and Friday, the second year students had class in the morning, and on Tuesday, Thursday and Friday, the first years had the morning. So, on Friday the second year and the first year were together and the second year was somewhat responsible for supporting and furthering the first year. That really worked very well. But it's not the way things fit into academic 'hour and 40 minute' schedules.

I had no aspiration in this world to be an academic. And I never thought of theatre as an academic subject. So, really, I didn't get into the history of drama, I didn't get into the great plays of the world or any of that stuff. I just was doing improvisational and character development. And later when I got more confidence in experiencing the Mudra work that I was studying, I brought that into my work. I think the threads that formed the curriculum were, first of all, of course, my work with improvisation through the Open Theater, my reading studies of Michael Chekhov's work, some Trungpa Rinpoche dharma teachings, and Mudra Space Awareness.

There really wasn't an academic subject. And that's not just me - the Arts at Naropa for a long time were not particularly trying to do the History piece and the Lit piece and the this and the that. The dancers were working with dance and meditation and contemplative view, and the musicians were doing the same, and we didn't have a visual arts course for a long time. So, the dance, music and theatre curricula were not what one is expected to offer now in order to call it a serious college programme. We had no desire to be a serious college anyway; college was not something that we were all that interested in. What was interesting to us was to teach our disciplines, not to have a college, and accreditation was out of necessity, not out of 'now we should be a college'. It was 'All right, they need their financial aid, so let's whip ourselves into shape so we can help them get it'.

\section{DANIEL}

Do you think that shaping the programme into something more academic in any sense interfered with the first vision you had of the place?

\section{LEE}

Well, that would probably depend on what the first vision of the place was. When you're working with somebody like Trungpa Rinpoche, probably every single person who 
was working with the 'vision' would tell you a different vision.

I think that I could safely say that Rinpoche felt that an approach to the whole person was important - the artistic process, the creative process, the contemplative process, the intellectual process, whatever other processes there are - that wholeness was important and different than what he was seeing in universities at the time. I think maybe everybody would agree on that. Certainly that's my bottom line vision - that it's not artists that do art and academics that do academic and other people do writing and so on - but that we are people and all these things contribute to a mind that has fluidity and can move in the direction that it needs to move in order to be alive and creative in a world that's ever-changing.

I do think that accreditation - because of the antiquity of the forms, so to speak - did start us in the direction of segregating things from each other; for a long time, not too badly. For a long, long time I had Master's degree Psychology students with undergraduate students in my classes and a wonderful mix of different programmes and different interests coming together. But then, little by little, it got so that the courses gave credit space for fewer and fewer electives outside of the major, especially on the Masters level with all the tests you have to take or credentials you have to have. Those psychologists couldn't take theatre class even though they felt it was really helping them in their training.

On the undergraduate level, when we started as a school, we were only offering the junior and senior years of a four year undergraduate programme. So we didn't have to deal with the general electives and fulfilling the thises and the thats. We were just offering majors, second two years on. You could get 60 credits in theatre or 50 credits in theatre and 10 credits in a minor in something else, or you could mix it up with all kinds of things. But then when we started wanting this 'real school' thing, cultivating a sophomore year and finally a freshman year, all sorts of things had to be included that weren't necessary when we were only doing junior and senior year. We had to have specific areas, and things like theatre - well, you still could get three credits of it as a body elective. You had to take three credits of body elective, three credits of contemplative, three credits from several different topics. I think there were five or six categories. So whatever electives you had, had to be spread out in those general courses; and, of course, if you have people coming in who are taking the course because it's one of the courses that can get you your three credits in bodywork, you're not on the same level as somebody who says, 'I'm a theatre major'. It's just two different reasons for taking theatre and, I find, you can't make the demands on somebody who's a theatre major if you've got people in the same class who don't even want to be seen on a stage. You can't treat some people like this and some people like that in the same class without confusing everybody. You have to keep finding a sort of middle; 'You can come, you can come, we can all do at least this', you know, and that's hard. That's really hard. 


\section{DANIEL}

May I say that this vision of theatre arts as a contemplative practice is, in some sense, approaching arts as a way or a path or vehicle for achieving this kind of wholeness, this kind of a more awake way of life?

\section{LEE}

I don't know. I mean... I would say that my experience of the people that I've worked with in the theatre is that it is a very alive way of life. There's a lot of ego junk, sometimes, in the profession. But as far as the training goes, as far as just playing goes, I think it's really very rich and very useful for anybody. But on the other hand, I don't know if that's really what you're asking me.

\section{DANIEL}

Well, sometimes we talk about the contemplative arts or, you know, now mindfulness, and I get thinking, what does 'contemplative' mean? You know, when we talk about contemplative theatre or contemplative arts or mindfulness and theatre, mindfulness and performance - what is it about? Of course, maybe we have a lot of answers for this question, but, in your vision, what do you think it refers to when we talk about contemplative arts, or mindfulness and arts?

\section{LEE}

The word mindfulness to my mind is... well, you know, you couldn't probably train in the arts if you weren't working with mindfulness. So I have to throw that one out - it's just kind of somebody's buzzword. As far as contemplative goes, I don't like that one either because so often it seems to mean something that's serious, and something that's calm, nobody has any emotions, and maybe slightly tinged with a sort of religious flavour - a holy kind of thing. I don't know if I like it, but I haven't found a better word. What do I mean by it? I think you're asking the question that I'm hoping you're receiving an answer to in the work we're doing here, because that's what I think of as contemplative.

I think it's very difficult to talk in any kind of general way about what is essentially personal experience of non-conceptuality. So, you know, you have to talk about it from your point of view because your point of view is the point of view that is your contemplative life experience. I mean, it's sort of like you're asking, 'Buddha, could you talk a little bit about enlightenment? Just tell me what enlightenment is?' It's not fair because you're mixing apples and oranges, or something like that, you know? What do you experience, what were the moments in this week when you had a sense of, 'Oh, yeah, that's... that's that contemplative...?' And then, what is the quality of those moments? Or what is the experience of those moments? Or how come you think of them as contemplative? I think one of my best talents is setting up situations within which people can discover their own answers. I think I'm pretty good at that. I certainly don't want to ruin their experience in any way by saying this is the experience. People are so used to grabbing onto the words and saying, 'Ah, now I get it'. Why would you want to do that to people when in fact you don't 'get' it? It uncovers. 


\section{DANIEL}

You told me that your first experience with Trungpa was special because he talked in that kind of way that you could recognize through your work with theatre, so did your work with theatre have some influence on your approach to Buddhist practice?

\section{LEE}

I think so, because I was a theatre person first. So whatever I learned as a young theatre person I'm pretty sure influenced my approach to Buddhism. I mean, how would I... why would I have taken so immediately to these Mudra theatre exercises, if I didn't know in myself that there was actually something that I needed for my training or for my discipline that I didn't have from my Western training? At the time I don't think I had any words for it. Thinking back on it, I reflect that it was always like feeling that there must be something more about theatre than personality - 'some people have presence, some people don't, some people are talented, some people aren't' - there must be something more to theatre than that. And the exercises of Mudra and sitting meditation definitely helped me connect with that missing piece from my own training; although experientially - well, you can't do ensemble theatre unless you're a little bit aware of space. There's just no way. And that was my favorite kind of theatre ensemble theatre.

\section{DANIEL}

During this moment that you were working on the programme, how did you approach the question of assessment? Did this contemplative aspect or Buddhist aspect in some sense influence assessment or was it, you know, more like, okay, we just have to do the assessment? Thinking about this aspect of wholeness - how to assess that?

\section{LEE}

Are you asking what I look for in a person that will tell me whether the person is getting it or not?

\section{DANIEL}

Yes!

LEE

I look for a lot of things. Is the person aware of the space? That's certainly part of it. Are their mind and body synchronized? That's definitely part of it. Noticing if their demeanor is becoming more gentle and less aggressive; if they're beginning to trust the space as a cocreator. All those things that I've been teaching all week, those are how I evaluate it. It's just by seeing if a person is getting it. And not everybody gets it.

Naropa is not a Buddhist university. Naropa was founded by a Buddhist teacher and some of the teachers who teach there, and who used to teach there, are Buddhists. But it's a university with a lot of other influences as well. I think that maybe one of the main ones that remains from the early days would be a real sense of non-competitiveness. Also, more willingness to accommodate the whole person rather than 'Well, but the due date is this, and if you don't get it in...'. There's a certain amount of that, it's not a flaky school in the 
way that sometimes it's thought of, but, you know, if your mom's having trouble, well, of course, you're in pain. Of course it's going to affect whether or not you get your paper in on time. I mean, what's the big deal? So you want a three day extension? Fine, okay. I mean, we're trying on a lot of levels to honour real life, and the people that we're helping and working with. At least at the beginning there was this sort of sense of 'You don't have to be doing this because you want to become an expert at it. You do it just because it's a passion of yours or because somehow it's something you've never explored before, or one thing and another'. That's less valued now.

We are spread out on three campuses now ${ }^{\mathrm{vi}}$, and most of the arts are on a campus that's not really that far from the main one but it's a bus ride or finding a way to drive your car there or something and there's only 20 minutes between classes so if the bulk of your classes are on the main campus.... once again, it's kind of excluding anybody but the artists from the arts. And there are very nice studios out there and even a music studio; it's a blessing to have such wonderful space, but it's a commute to it for people who aren't in the arts programme. So it starts to separate out the academic programme from the artistic process programme.

\section{DANIEL}

In a contemplative theatre practice, what is the role of technique? What, do you think, is your approach to technique?

\section{LEE}

When you say technique, do you mean something like the Method or the Grotowski technique?

DANIEL

Yeah.

LEE

Well, I don't have one. After all. I mean... you know, a little Grotowski, a little Open Theater, a lot of Mudra, a certain amount of things that I make up. I think it's my technique.

\section{DANIEL}

But what if I ask you - what is the role of technique?

LEE

For acting?

DANIEL

Yeah.

\section{LEE}

In professionalism, or in living or in what?

\section{DANIEL}

In acting.

\section{LEE}

The role of technique in acting, I think, is the way you begin to bring your mind, body, and bodhichitta ${ }^{\text {vii }}$ to the world - as a statement, rather than as a scattering of ideas. Synchronizing yourself so that the performance is not muddy, you know? 


\section{DANIEL}

So, technique is a way to express your bodhichitta commitment - a way to relate with reality?

\section{LEE}

With space. Yeah, I think so. I think without a synchronization of mind and body, you're not going to arrive at opening up a bodhichitta heart, because it's all too self involved, too much trying to hold itself together in order to believe that it exists. As long as all the focus is on that, holding on to that, not shattering that identity and so on, you don't have any time for anything else. Only when that part is finally settled, finally relaxed, can you turn outward to the world and take a look at what's going on out there. I think that's why Trungpa Rinpoche had us sit down. Sit down. Follow the breath. Follow the breath. Don't start trying to help anybody else until you've ceased putting out garbage. That's what he called it - garbage. Don't make more garbage; you know, get yourself together. Now, of course, there are all kinds of arguments - 'Oh, if we wait till we get it together, it will be too late in our lives'. But that's Western people thinking linearly. If you're enlightened right now actually, underneath all that scuzz, why not just rip off the scuzz? It's not going to take forever to get there. If you're going to go on that long route, you'll never get rid of it all. I mean, this idea that you can't rest your mind... I have acquaintances from the early days who still say, 'My mind is just going everywhere; I just can't settle it down'. I'm thinking, 'Honey you've been practicing for 45 years, and you haven't got a handle on your mind yet?
Something is missing in your practice, in your technique'. There are so many wonderful meditation techniques. There's really no reason why anybody shouldn't find one that works for them, stick to it and go for it, unless really what they want is something else and they just say they want liberation, which, I believe, in many cases is the truth. Maybe they want the society, or maybe they want to rub up against that nice looking teacher, or maybe they think it's going to, you know, give them status.

\section{DANIEL}

But not the hard work...

\section{LEE}

They don't really, really want to let go of the thing that's causing them suffering.

\section{DANIEL}

... put their hands on garbage...

\section{LEE}

That's right. They like the garbage too much. I think that is the role of technique, to take out the garbage. But, in that sense, it doesn't necessarily have to be an acting technique. I suppose if you want to be an actor, you need to be able to speak loud enough to be heard and you need to be able to have a body that's fluid enough to express what you're communicating, but many techniques can do all of that. If you haven't trained the mind behind all of that, technique only goes so far. When the klesha - or negative emotions activity comes in, you're in turmoil again, and that's not so good. Mudra intensification 
practice is really helpful because... definitely in my experience the hardest place to really be authentic on stage is when you've got an audience in front of you. Because there are so many possible ways that you can get hooked into their minds, so many ways that your own sense of what you're doing is compromised by having to battle the airwaves, you know? So that kind of technique - I would say probably sitting meditation is the technique that everybody should have as the bottom line; as an artist, just to tame the mind down. And then on top of that, the training could be a Buddhist training or athletic training or voice training or whatever. But without that resting mind, it's not going to be satisfactory.

'You are your own Mudra'viii fits in here a little bit, in that the resting mind rests on the ground of 'things being perfect just the way they are'. That perfection can't happen unless your mind really is resting. You can't just say that. You have to know that; know that in a non-conceptual way, in the rock meets bone way. And I think that only meditation practice can do that for you. They say, in fact, that scholarship can take you a ways on the path, and it is certainly useful to have the scholarship, but finally one has to have that real practice experience.

So, what do you think about that from your practice point of view?

\section{DANIEL}

So, for me, the notion of suffering - Dukkha, you know - as ignorance, and when you can see your ignorance and try to work on that - I think this makes a lot of difference in the way we work and the way we approach our selves. Well, this is what I'm trying to do. Actually this programme was much more than I expected. It was overwhelming in some ways, because of this kind of mirror that practice puts in front of you. And in some ways it reminds me of when I did a Mahamudra retreat (first level) with Mingyur Rinpoche. It was two months. And at the end of the two months, I was like, 'Oh my gosh, I think I prefer the ignorance', you know? Because samsara is not good. It's painful! In some sense, yeah, I'm feeling the same. It's not something like 'Oh, I'm suffering'. No, it's not that. It's just recognizing the condition.

And today - this afternoon - I was tired and I didn't want to go to the Mudra Space Awareness exercise. I was afraid. I was afraid of what people will think. I was afraid of everything, a lot, and then I thought, 'Come on. There is no other option'. And it is this kind of practice of 'Okay, let's have a go and see what happens. Be open to the experiences'. I think that the integration of all those experiences will not come now.

\section{LEE}

No. No, it really takes its own time to grow.

\section{DANIEL}

I remember on the second day, I was 'flickering ${ }^{i x_{1}}$ and then we had an interval and I went out and I started to watch the trees and the environment. It was like when I was a child. And so I thought, 'Wow, that's possible'.

\section{LEE}

Yeah. It's not only possible, it's important. 


\section{DANIEL}

This experience has been so striking in some points, so challenging.

\section{LEE}

Well, I hope it's been challenging because it's meeting your aspiration, rather than that it's just stuff that takes one to the edge of the cliff, maybe more for sensationalism or something like that. I really try to stay away from that. I really try to make a situation where one can go at one's own pace, except that one needs kind of a little nudge to go at that pace. But I do hope that I... I don't know how I could make it any more user-friendly, actually.

\section{DANIEL}

Well, the last question: do you have any artist or group that you think for you is a reference or in some way is doing this work of bringing together meditation or Buddhism and theatre? I ask because the impression I have, doing the research now, is that we are so few really trying to do something like that. I've met some theatre practitioners who say their work is contemplative practice, but when I was there watching them... I thought yes, it is a kind of improvisational thing, or embodied thing, but it's different from, for example, what I am experiencing here. With them, I didn't have this experience of a mirror, or something like that.

\section{LEE}

Rinpoche was never suggesting that the Mudra work is performance. It is training. You don't want to put this training on the stage any more than you want to put Grotowski's 'Cat'x on the stage. It's just training. Then you go and you do whatever you do, but you do it because you are a contemplative, not because you have a technique that you are putting out there. And if the person has not yet become seasoned with a contemplative mind, there's no way to fake it. Really, there's no way to fake it. There's no point in faking it. Better to be a baby contemplative and be honestly who you are - your own mudra - than to think of yourself as a contemplative when everybody knows you are a phony.

\section{DANIEL}

Yeah, this is the point. I think the people who I have met and who in some sense impressed me in this field... like, Bill Viola, you know, when you go to an exposition, or some works of Meredith Monk - those people have some practice.

\section{LEE}

Yes, definitely. I think Meredith should be on that list. I would also put Leonard Cohen on that list, but he's not a theatre person.

I think more and more that, at least at Naropa, that was the direction that we went in, and maybe still go in - interarts. Not 'this is the theatre', 'this is the dance'. We had classes where the musicians were teaching the theatre people, and the dancers were teaching the musicians, and some of the classes were just classes in creative process taught by people who were teachers in specific disciplines but were also trying to look for disciplines in creative process that went beyond music or dance or theatre, and that 
was really exciting. Those were really exciting times, I thought.

I always felt theatre was in the best position because to train as an actor you really do need to be trained in music and in dance as well as in acting. The hardest challenge, it seemed like, was for the dancers who didn't want to touch the emotional body at all.

\section{DANIEL}

That's interesting! In my university the student goes to the acting class, and then after that they go to the directing class. And you see one thing and another thing, and most of the time they don't dialogue.

\section{LEE}

That actually brings us back to one of your questions, which was something about Naropa's approach. Many times students have reflected back to us how awesome it is to be in one class and be talking about something and to then go to another class and have the same discussion from a different angle, or a different discipline, and that they begin to see themselves as the thing that's being studied with all these influences coming from different directions. I think that's really a mark of the Buddhist approach. What we are talking about is the nature of mind. You can talk about it through this lens and that lens and the other lens, but finally the arrows all point to you and your own mind. And my own mind. And that is where the integration occurs.

\section{References}

Middleton, D. \& D. Plá (2018) 'Adapting the Dharma: Buddhism and Contemporary Theatre Training' in Journal of Global Buddhism, Vol. 19, pp. 113-125.

Slowiack, J. \& J. Cuesta (2007) Jerzy Grotowski. New York: Routledge.

Williams, P. (2009) Mahāyāna Buddhism: The Doctrinal Foundations ( $2^{\text {nd }}$ edition). New York: Routledge.

Worley. L. (2001) Coming From Nothing: the sacred art of acting. Boulder: Turquoise Dragon Press.

${ }^{\mathrm{i}}$ For discussions of Mudra Space Awareness, see Lee Worley (2001) Coming From Nothing: the sacred art of acting. Boulder: Turquoise Dragon Press, pp. 119 - 137; Deborah Middleton \& Daniel Plá (2018) 'Adapting the Dharma: Buddhism and Contemporary Theatre Training' in Journal of Global Buddhism, Vol. 19, p. 113-125.

ii In 1962, while studying at the Neighborhood Playhouse, Lee began attending workshops which were conducted by students of acting teacher Nola Chilton, including Joseph Chaikin. Nola had recently left New York for Israel and the group wanted to continue working together. Some members of this group later became the core of the Open Theater. The Open Theater was an experimental ensemble directed by Joseph Chaikin, active from 1963 to 1973 . The work was based on the centrality of the actor; the exploration of voice and acting exercises through workshops; collaborative creation; and open improvisation.

iii The talks are on file in the Naropa University library.

iv At that time the "Seminary" was a three month retreat led by Chogyam Trungpa in which his students studied meditation and the three vehicles 
of Tibetan Buddhism in preparation for becoming Vajrayana students.

${ }^{v}$ Lee left New York City in 1972, moving with 3 month old daughter Jessica and her father Dale Whitt to Santa Fe. There she founded an acting ensemble called, "Wit's End."

${ }^{\text {vi }}$ This description was correct at the time of the interview in 2016.

vii According to Williams (2009, 194-195), Bodhicitta is the authentic motivation in the Mahayana School; the "Mind of Enlightenment or Awakening Mind" that comes from deep concern for the suffering of oneself and others. In this direction, it embraces the aspiration of freeing all sentient beings by means of practicing the eightfold path. Williams, P. (2009). Mahāyāna Buddhism: The Doctrinal Foundations ( $2^{\text {nd }}$ edition). NY: Routledge

viii This is a slogan from Mudra Space Awareness (MSA) which was used several times during the retreat.

${ }^{i x}$ Flickering refers to an exercise we did in the MSA retreat, in which participants attend to the senses so the mind has no single point of focus but flows from one perception to another. Instead of narrowing the attention to an object, it expands it to the space and all sense perceptions.

${ }^{x}$ The cat exercise is inspired by the movements of a cat waking up and stretching. A detailed description can be found in Slowiak J. \& J. Cuesta (2007) Jerzy Grotowski. New York: Routledge. 